\title{
Stereotypy w dowcipach macedońskich
}

\author{
Stereotypes in Macedonian jokes
}

\author{
Magdalena Błaszak \\ Wydział Filologiczny, Uniwersytet Śląski \\ pl. Sejmu Śląskiego 1, 40-032 Katowice, Polska; \\ magdalena.blaszak@us.edu.pl
}

\begin{abstract}
Abstrakt
Artykuł Stereotypy $w$ dowcipach macedońskich ma na celu ukazanie, że dowcipy powstają dzięki stereotypom, są przez nie utrwalane i rozpowszechniane. Stereotypy występują w każdej grupie społecznej, przekazują tradycję społeczną z pokolenia na pokolenie, pomijając fakt, że dany obraz grupy przez wiele lat ewoluował. Autorka w artykule podaje przykłady macedońskich dowcipów o różnych grupach narodowych, społecznych czy etnicznych. Na tej podstawie przedstawia zarówno uprzedzenia Macedończyków występujące na przykład w stosunku do określonych narodowości, jak i pozytywne postrzeganie tych nacji. Przedmiotem badań są dowcipy zaczerpnięte z macedońskich stron internetowych, a zastosowana przez autorkę metoda badawcza pozwala na klasyfikację treści według różnych rodzajów stereotypów: etnicznych, narodowych, klas zawodowych czy grup społecznych.
\end{abstract}

Slowa kluczowe: stereotypy; komizm; dowcip.

\begin{abstract}
The goal of the article Stereotypes in Macedonian Jokes is to demonstrate that jokes are based on stereotypes which tend to be consolidated and disseminated by means of jokes. Stereotypes occur in every social group, they hand down social tradition from generation to generation despite the fact that a picture of a group in question has evolved for many years. The article provides examples of Macedonian jokes about various national, social and ethnic groups. These examples serve to present Macedonian prejudices as well as a positive perception of the mentioned groups. The research is based on jokes downloaded from Macedonian websites. The research methodology allows to classify the content into different types of stereotypes: ethnic, national, related to professions or social groups.
\end{abstract}

Keywords: stereotypes; jokes; humour.

Stereotypy są szeroko rozpowszechnionym zjawiskiem kulturowym, występującym w każdej grupie społecznej. Ukazało się już wiele publikacji na ich temat, ale pomimo to nie maleje zainteresowanie nimi. Celem niniejszego artykułu jest ukazanie, że dowcipy powstają dzięki stereotypom, a te są z kolei przez nie utrwalane. W artykule podam przykłady macedońskich dowcipów przedstawiających stereotypy występujące w tym języku. Głównym kryterium wyboru analizowa- 
nych tekstów była frekwencja. Materiał do analizy został wyekscerpowany z macedońskich stron internetowych, a zastosowana przeze mnie metoda badawcza pozwoliła na klasyfikację treści według różnych rodzajów stereotypów: etnicznych, narodowych, klas zawodowych czy grup społecznych.

Macedońscy lingwiści nie prowadzą szeroko zakrojonych badań związanych $z$ humorem czy stereotypami. W opracowaniach dotyczących tego języka spotkałam stosunkowo niewielką liczbę artykułów na temat interesującego mnie zagadnienia, które zawężone były głównie do przedstawienia obrazu kobiety w języku.

Pierwsza część artykułu stanowi ujęcie teoretyczne interesującego mnie zagadnienia, natomiast $\mathrm{w}$ drugiej części przedstawiam zgromadzony materiał stereotypy z kultury słowiańskiej, dość odległej, słabo (jeśli w ogóle) znanej w Polsce.

Pojęcie stereotypu występowało już w języku greckim. Stereos to odpowiednik słów 'stężały, twardy', a typos to 'wzorzec, odcisk'. Ma to związek z pierwotnym znaczeniem słowa stereotyp. W drukarstwie określało ono odlewy składu drukarskiego przeznaczonego do druku dużych nakładów albo dalszych wydań, które pozostawały bez zmian (Kopaliński 2000: 473). Według Słownika języka polskiego stereotyp to „wyobrażenie o jakichś ludziach, rzeczach lub zjawiskach, utrwalone w świadomości wielu osób i trudno poddające się zmianom [...]" (Bańko red. 2007: 185).

W książce Public Opinion wydanej w 1922 r. Walter Lippmann umieścił swoją definicję stereotypu. Określił to pojęcie prawdopodobnie pierwszy, pisząc o „obrazach w naszych głowach (pictures in our head)” (cyt. za Walczyńska 1998: 304). Obrazy te są konsekwencją bodźców ze świata zewnętrznego, które człowiek przetwarza w charakterystyczny dla siebie sposób, to forma postrzegania poprzedzająca wykorzystanie umysłu (Walczyńska 1998: 305).

Najobszerniej pojęcie stereotypu przedstawił Hilary Putnam, pozbawiając go negatywnych asocjacji. Większość definicji kojarzy nam się z uprzedzeniem, negatywnym osądem, brakiem obiektywności oraz powierzchownością, a to nie jest sprawiedliwa ocena. Putnam przedstawia stereotyp w zupełnie innym świetle, mówiąc o swoistych cechach zjawiska bądź przedmiotu przyjętych za właściwe w określonym kręgu kulturalnym (por. Libura 1998: 296).

Lingwistyczne rozumienie stereotypu można sprowadzić do trzech aspektów:

1. stereotyp jest reprodukowalnym związkiem wyrazowym (stereotyp lingwalny);

2. stereotyp jest specyficznym konstruktem mentalnym (stereotyp mentalny);

3. stereotyp jest specyficznym konstruktem mentalnym zakorzenionym w świadomości poprzez znak językowy (stereotyp lingwomentalny).

Ujęcie 1. traktuje się dziś jako mało aktualne i marginalne, granica zaś między ujęciem 2. i 3. nie jest zaznaczona ostro (Chlebda 1998: 34). Przedstawione powyżej różnice w sposobie rozumienia pojęcia stereotypu ukazują nam jego złożoność i wieloaspektowość. 
W rzeczywistości kulturowej stereotyp spełnia trzy funkcje, które współwystępują, są współzależne:

1. funkcję kognitywną - wszelkie radykalne uogólnienia dokonywane w procesie przyswajania informacji - np. przy obserwacji osobliwości obcej kultury [...];

2. funkcję afektywną - pewien określony stopień etnocentryzmu w kontaktach międzyetnicznych jest z punktu widzenia kształtowania się tożsamości i stabilności psychiki danej wspólnoty całkowicie funkcjonalny;

3. funkcję społeczną - rozgraniczenie bycia w grupie - bycia poza grupą i odpowiednie społeczne kategoryzacje są sposobem, w jaki sami członkowie danej społeczności wypracowują sobie strukturę społeczną (Quasthoff 1998: 14).

Podsumowując, można powiedzieć, że funkcja poznawcza jest odpowiedzialna za przetwarzanie informacji i klasyfikację zjawisk, funkcja wartościująca pozwala nam na ich ocenę, a dzięki funkcji społecznej wyróżniamy się na tle innych grup.

Stereotypy bazujące na błędnej informacji są trudne do zmiany, nie wystarczy zweryfikować daną informację, aby usunąć stereotyp. W swoim artykule Jolanta Panasiuk przedstawiła tezę o ich zmienności, co jest sprzeczne z najpopularniejszą definicją stereotypu. Została ona postawiona na podstawie analizy danych $\mathrm{z}$ dwóch ankiet przeprowadzonych $\mathrm{w}$ odstępie 10 lat. Pierwszą ankietę przeprowadzono w latach osiemdziesiątych XX wieku. Badania wykazały, że wbrew powszechnie przyjętym opiniom stereotyp może ulec zmianie (por. Panasiuk 1998: 85). Najłatwiej zmianom ulegają stereotypy słabo zakorzenione w świadomości ludzkiej, takie, które nie mają swoich odpowiedników na przykład w związkach frazeologicznych czy przysłowiach.

Najtrafniejszą definicją stereotypu wydaje się stereotyp jako językowy obraz świata, gdyż dopuszcza on zmienność, jako że wraz ze zmianami rzeczywistości mogą zmieniać się i stereotypy (por. Dzemidok 1967: 15).

Zanim przedstawię stereotypy zakorzenione w świadomości Macedończyków, nawiążę jeszcze do pojęć związanych z komizmem i dowcipem. Komizm trudno jest zdefiniować jednoznacznie. Autorem jednej z pierwszych definicji komizmu jest Arystoteles, dla którego komizmem są ujemne cechy natury duchowej i fizycznej, jak na przykład brzydota, ale takie cechy, które nie wywołują cierpienia. Tak pojmowany komizm nie thumaczy wszystkich jego rodzajów, jego definicja jest zbyt ograniczona (por. Dzemidok 1967: 15).

Szersze określenie komizmu wprowadza do języka Hobbes, który definiuje je następująco: „Poczucie śmieszności jest to nagle powstałe uczucie wyższości i samozadowolenia wynikające $\mathrm{z}$ nieoczekiwanego uświadomienia sobie przewagi nad kimś, kto zachował się niewłaściwie, lub w inny sposób wyraził swoją niższość" (cyt. za Dzemidok 1967: 17).

Wyróżnia się trzy rodzaje komizmu:

1. sytuacyjny - polega na bawieniu widza spiętrzeniem niefortunnych i niezwykłych wypadków, wymuszających na bohaterze zachowanie śmieszne i komiczne; 
2. postaci (inaczej charakterologiczny) - polega on na umiejętnym dobieraniu typów bohaterów w taki sposób, aby uwypukleniu uległy pewne cechy charakteru, jak na przykład głupota czy też chciwość;

3. słowny (inaczej komizm językowy) - na widza oddziałuje przede wszystkim żart, dowcip, jaki pada ze sceny. Są to często zabawne dialogi bohaterów czy też żartobliwe powiedzonka (www 1).

Przedmiotem mojego zainteresowania w niniejszym artykule jest komizm słowny widoczny w dowcipach macedońskich ukazujących stereotypy zakorzenione w świadomości mieszkańców Macedonii.

W każdym państwie istnieje pewien autostereotyp narodowy, czyli jego własny obraz, z którym się identyfikuje. Jest on przeważnie pozytywny, pełen zalet. Charakteryzując własną grupę, nie oceniamy jej negatywnie, a wręcz przeciwnie, mamy skłonność do bagatelizowania negatywnych cech. Polak według Polaka nie jest złodziejem, a zdolnym do improwizacji, dynamicznym i pełnym fantazji człowiekiem (Brzozowska 2008: 47). Nie jesteśmy jedynym krajem, który ubarwia istniejące na jego temat stereotypy. Także Macedończycy według siebie są gościnni, odważni, inteligentni i grzeczni. Spotykamy się także z pojęciem heterosteretypu, czyli stereotypowych opinii na temat grupy obcej. Są one tworzone dla ludzi bądź narodów, którzy są istotni z powodu wiążących z nimi ważnych relacji lub według których ustalana jest własna tożsamość narodowa. Najczęściej heterostereotypy są przeciwieństwem własnego obrazu. W potocznym języku, mówiąc o stereotypach, mamy na myśli właśnie heterosterotypy (Brzozowska 2008: 22-23). Macedończycy to mały, cichy i skromny naród. Swoje kompleksy leczą odwoływaniem się do starożytnej Macedonii i chwały Aleksandra Macedońskiego. Nienawidzą Albańczyków, bo ci chcą odebrać im połowę kraju i panoszą się w nim. Nie przepadają też za Grekami, ale nie dlatego, że Grecy panoszą się w ich kraju, ale dlatego, że ci głoszą wszem i wobec, że Macedończyków po prostu nie ma, tak samo, jak nie ma ich ukochanej ojczyzny o nazwie Macedonia. A że Greków świat słucha uważniej od tych, których rzekomo nie ma, to problem wydaje się poważny. Macedończycy nie zamierzają Grekom ustępować (i słusznie), a Grecy będą się wciąż wyzłośliwiać, dopóki Macedończycy nie nazwą swojego państwa np. Republiką Wardarską. Macedończycy marzą jednak po cichu o Wielkiej Macedonii obejmującej także ziemie historycznej Macedonii leżące w Grecji, Serbii, Bułgarii i Albanii. Tym samym denerwują Bułgarów, którzy są zdania, że Macedończycy to Bułgarzy, którym poprzewracało się w głowach od mieszkania w Jugosławii. Dla Bułgarów Macedończycy są głupiutkim młodszym braciszkiem, który musi się wyszaleć, ale ostatecznie musi zostać przywołany do porządku. Z tych też powodów w Macedonii najbardziej widoczny jest stereotyp Greka, Albańczyka i Bułgara.

Te stereotypy narodowe, ośmieszające kraje sąsiedzkie, często pojawiają się w dowcipach macedońskich. Do ich rozpowszechniania może prowadzić sytuacja polityczna, religijna lub gospodarcza. Dowcipy etniczne umacniają odrębność na- 
rodową danego kraju, gdyż są oparte na przeciwstawieniu „swoi - obcy”. Dowcipy etniczne są z zasady złośliwe, prześmiewcze, a nawet agresywne. Obrażają grupy etniczne, narodowe, często przypisując im nieprawdziwe cechy (Brzozowska 2008: 29-30).

Грк, Албанеи и Бугарин фатиле златна рипка.

- Сакам во Македонија да има ерупиија на вулкан - рекол Гркот.

- Сакам во Македонија да има поплава - рекол Бугаринот.

- Сакам во Македонија да има земјотрес - рекол Албанеиот.

- Готово - рекла рибата...

Гледаат сред Солун изникнал вулкан, Бугарија била поплавена со вода, а Албанија била срамнета со земја. - ЗЛАТНА РИПКЕ, ШТО НАПРВИ?!!!

- ИИИ, ИЗВИНЕТЕ ГЛЕДАВ СТАРА КАРТА ОД МАКЕДОНИЈА ${ }^{1}$

Grek, Albańczyk i Butgar złapali złota rybkę.

- Chciatbym, żeby w Macedonii byta erupcja wulkanu - powiedziat Grek.

- Chciatbym, żeby w Macedonii byta powódź - powiedziat Butgar.

- Chciatbym, żeby w Macedonii byto trzesienie ziemi - powiedziat Albańczyk.

- Gotowe - powiedziała rybka...

Patrza, a w centrum Salonik wybuchnat wulkan, Butgaria była zalana woda, a Albania została zrównana z ziemiq - Zlota Rybko, co zrobitaś?!

- Przepraszam, patrzylam na stara mape Macedonii ${ }^{2}$.

На аеродром се сретнуваат македонеи и грк. И гркот го прашува македонеиот: Од каде сте вие? - на што македонецот одговара: „Од Македонија”.

„,Ооо која ко коинциденција!” - вика гркот.... Јас сум од Гриија, тоа е балкан, колку е светот мал?! - се зачудил гркот.

„Не е светот мал” - му одговори македонецот... МАКЕДОНИЈА Е ГОЛЕМА!

Na lotnisku spotyka się Macedończyk z Grekiem. Grek pyta Macedończyka:

Skad Pan jest? Na co Macedończyk odpowiada: „Z Macedonii”.

„,Ooo, jaki zbieg okoliczności” - woła Grek - Ja jestem z Grecji, to też Batkany, jaki ten świat maty... - zdziwit się Grek.

„To nie świat jest maty” - odpowiedziat mu Macedończyk-Macedonia jest wielka!

Што е разликата помеѓу Македонија и Гриија?

- Македонија прави историја, а Гриија долгови.

Jaka jest różnica pomiędzy Macedoniq i Grecja??

- Macedonia tworzy historie, a Grecja dlugi.

Bohaterkami niezliczonej ilości dowcipów, podobnie jak w Polsce, są kobiety o włosach w kolorze blond. Teksty te najczęściej zaczynają się od frazy wprowatykułu.

${ }^{1}$ Spis źródeł internetowych, z których pochodzą cytowane dowcipy, znajduje się na końcu ar-

2 Thumaczenie wszystkich tekstów jest mojego autorstwa. 
dzającej: Rozmawiaja dwie blondynki... Dowcip może kończyć się na różne sposoby, ale najczęściej świadczy o ich braku inteligencji. Szeroko rozpowszechniony stereotyp głupiej blondynki chyba już na stałe zakorzenił się w świadomości każdego odbiorcy. Mimo iż włosy koloru blond są symbolem młodości i piękna, a w licznych bajkach czy legendach księżniczki to złotowłose, anielskie istoty, blondynki przedstawiane są w dowcipach jako niezorientowane i nieporadne kobiety. Macedoński humor także ukazuje stereotypowe postrzeganie kobiet o jasnym kolorze włosów:

Плавуша му кажува на сопругот дека сака да посвои тримесечно бебе од Англија. Сопругот ја прашува:

- Што ќе правиш со него??

- Па кога ќе почне да зборува, од него ќе учам англиски.

Blondynka mówi mężowi, że chce adoptować trzymiesięczne dziecko z Anglii.

Mąż ja pyta:

- Co będziesz z nim robić?

- Kiedy zacznie mówić, nauczę się od niego angielskiego.

Бринета прамува плавуща:

- Колку калории можам да согорам, ако пливам иел час во базенот?!

А плавушата враќа:

- Глупа жено! Не можеш да гориш работи во вода!

Brunetka pyta blondynkę:

- Ile kalorii mogę spalić, jeśli będę plywać cała godzinę w basenie?

A blondynka odpowiada:

- Gtupia kobieto, nie da się niczego spalić w wodzie!

Зошто плавуша отвора млеко во продавница? - Бидејќи на пакувањето пишува ОТВОРИ ОВДЕ.

Dlaczego blondynka otwiera mleko w sklepie? - Ponieważ na opakowaniu jest napisane TUTAJ OTWIERAĆ.

Зошто плавушата става часовник на рана? Викаат дека времето ги лечи раните.

Dlaczego blondynka kladzie zegarek na ranę? Ponieważ mówiq, że czas leczy rany.

Podobnie jak w Polsce, także w Macedonii istnieje wiele dowcipów na temat teściowej. Przedstawiana jest ona w nich jako kobieta wścibska i wredna. Dotyczy to głównie matki męża, która rości sobie prawo wyrokowania, co jest najlepsze dla jej syna. Funkcjonujący w naszej świadomości stereotyp teściowej sprawia, że pewne jej działania i nieopaczne stwierdzenia częstokroć uważamy za jego potwierdzenie. 
Се договараат снаи и свекрви ќе одат на екскурзија. И решиле да се поделат со автобусите, во едниот снаите, во другиот свекрвите. И снаите како помлади му дале предност на свекрвите да се возат напред со автобусот. И како што патувале, автобусот со свекрвите направил сообраќајка и ниедна од нив не преживеала. Снаите почнале сите да се радуваат да се смејат, арно ама само една од нив се отепала од плачење. Сите почнале да се чудат што е работата со оваа и откако ја прашале зошто плачи таа им одговорила:

- Како да не плачам. Мојата свекрва не стигна да го фати автобусот... остана дома!!!

Synowe i teściowe umówity się, że pojada na wycieczkę. Zdecydowaty, że podziela się autobusami - do jednego wsiadty synowe, a do drugiego teściowe. Synowe, ze względu na to, że sa młodsze, pozwolity, by teściowe jechaty pierwsze. Podczas podróży autobus z teściowymi miał wypadek $i \dot{z} a d n a ~ z$ nich nie przeżyła. Synowe zaczęty się cieszyć i śmiać, a tylko jedna z nich płakała. Wszystkie zaczęty się dziwić i pytaty, dlaczego płacze, a ona im odpowiedziała:

- Jak mam nie płakać. Moja teściowa nie zdążła na autobus... została w domu!!!

Се оженил синот и дома ја довел новата снаа. Првото утро свекрвата и снаата пијат кафе, а свекрвата вели:

- Да ти кажам уште на почеток - јас секое утро си станувам, седнувам да пијам кафе и ако закачам каранфил на левото уво не ми се обраќај и не ме прашувај ништо бидејки сум многу лута и нервозна. Ако каранфилот е на десна страна, добра сум.

- А јас секое утро си станувам - продолжува снаата - се туширам, дрмам две-три ракии и ич не ми е гајле на која страна ти е каранфилот.

Pewien mężczyzna się ożenit i przyprowadził synowa do domu. Pierwszego ranka teściowa i synowa piją kawę i teściowa mówi:

- Powiem ci na początku - każdego ranka wstaję, siadam, żeby się napić kawy i jeśli wsunę goździka za lewe ucho, nie zwracaj się do mnie po nic, ponieważ jestem bardzo zła i nerwowa. Jeśli goździk będzie po prawej stronie - będę dobra. A ja każdego ranka wstaję - mówi synowa - biorę prysznic, piję dwie-trzy rakije i w nosie mam, po której stronie masz goździka.

Także w obrębie różnych grup zawodowych czy też branż widoczna jest przesadna generalizacja. Ujawnia się ona w dowcipach o lekarzach, informatykach czy też policjantach.

Powszechnie wiadomo, że naukowiec często nie wykazuje zainteresowania rzeczywistością, bywa rozkojarzony i roztargniony. W języku powstał stereotyp informatyka, który, żyjąc w cyberprzestrzeni, w internecie, często zapomina o otaczającym go świecie. Widać to także w dowcipach macedońskich na temat tej grupy zawodowej:

Се возат проект менауер, компјутерски програмер и компјутерски оператор по пат и им се дупнала гумата. Тројиата се обидуваат да го решат 
проблемот. Проект менаиерот вика:

- Ајде да земеме такси и за 10 минути сме до саканата дестинаџија.

Компјутерскиот програмер вика:

- Ајде да го прочитаме упатството: Можам да ја сменам гумата и продолжиме со возење.

- Компуутерскиот оператор вика:

- Најпрвин, да го изгаснеме моторот, да го запалиме повторно. Може тоа ќе ги реши проблемите.

Наеднаш, се појавува Microsoft софтверски инженер и вика:

- Пробајте да ги затворите сите прозоричи, излезете од колата, пак влезете во колата и пробајте повторно!

Jada menadżer, programista i operator komputerowy i złapali gumę. Cała trójka myśli, jak rozwiąać problem. Menadżer mówi:

- Weźmiemy taksówkę i za 10 minut będziemy na miejscu.

Programista mówi:

- Przeczytajmy instrukcję: moge zmienić koło i będziemy kontynuować podróż.

Operator komputerowy mówi:

- Najpierw zgaśmy silnik i zapalmy ponownie. Może to rozwiąże problem.

Nagle pojawia się inżynier Microsoft $i$ mówi:

- Spróbujcie zamknąć wszystkie okna, wyjdźcie z samochodu, znów wsiądźcie

i spróbujcie ponownie zapalić!

Како програмер се качува на 12 кат со лифт?

Притиска на 1-ви, притиска на 2-ри и бара кај е Enter.

Jak programista wjeżḋa windą na 12. piętro?

Przyciska na 1 i 2 i szuka Enter.

Kolejną grupą zawodową wyśmiewaną w dowcipach są policjanci. Są oni postrzegani jako ludzie tchórzliwi o niskim ilorazie inteligencji, łapówkarze. To krzywdzące uogólnienie jest źródłem komplikacji w relacjach społecznych ze względu na brak szacunku względem funkcjonariuszy.

Си доаѓ полицаецот дома и ја гледа својата жена како лежи гола во креветот.

- Жено кажи каде е! Ке го убијам!

- Никој нема мажу, ито ти е?

- Мори жено кажувај каде е, ќе ве убијам двајцата.

- Никој нема!

Оди во едната соба никој, оди во другата нема никој. Отвара го шкафот и таму нема никој. Погледнува под креветот, а од таму човекот му подава 20 евра. Полицаецот ги зема парите и вели:

- И под креветот нема никој!

Przychodzi policjant do domu i widzi swoją żonę naga w tóżku.

- Żono, gdzie on jest! Zabije go!

- Nikogo nie ma mężu, co ci jest?

- Powiedz żono, inaczej zabiję was oboje. 
- Nikogo nie ma!

Idzie do jednego pokoju, nie ma nikogo, w drugim też. Otwiera szafę i tam też nic.

Patrzy pod tóżko, a tam człowiek daje mu 20 euro. Bierze pieniadze i mówi:

- I pod łóżiem nikogo nie ma!

Влегува полицаеи во ирква и започнува да ги дува свеќите. Попот оди до него и го прамува:

- Зошто ги дуваш свеќите?

- Како зошто?! Денес ми е роденден!

Wchodzi policjant do cerkwi i zdmuchuje świeczki. Podchodzi pop i pyta:

- Dlaczego zdmuchujesz świeczki?

- Jak to dlaczego?! Dziś mam urodziny!

Зошто мозокот од полицаеиот е најскап?

- Затоа што ич не е искористен!!!

Dlaczego mózg policjanta jest najdroższy?

- Ponieważ nigdy nie byt używany!!!

Kolejnym stereotypem jest powszechnie głoszony pogląd, że lekarze to niedouczeni łapówkarze, niewykazujący zainteresowania pacjentem. Potwierdzenie tego znajdziemy w macedońskich dowcipach o lekarzach:

Во операциона сала, неколку минути пред да прими анестезија, пациентот го прашува докторот:

- Докторе, успешна ли ќе биде операцијата?

- Не се плашете господине, ова ми е 70ти пат.

- Значи немам гајле?

- Без грижа, еднаш мора да ми успее.

W sali operacyjnej, kilka minut przed uśpieniem pacjent pyta lekarza:

- Doktorze, operacja się uda?

- Proszę się nie bać, to już mój 70. raz.

- Czyli mam się nie bać?

- Bez obaw, kiedyś musi mi się udać.

Głównym celem artykułu było ukazanie, że dowcipy powstają dzięki stereotypom, są przez nie utrwalane i rozpowszechniane. Ukazują emocjonalne postawy wobec poszczególnych grup społecznych, a stereotypy przekazują tradycję społeczną. Większość z nich zawiera negatywne asocjacje, których korzenie sięgają odległej przeszłości poszczególnych narodów.

Wszystkie przedstawione przeze mnie stereotypy należą do negatywnych szablonów postrzegania poszczególnych grup przez innych. Dowcipy opisujące najbliższych sąsiadów Macedończyków mają związek ze stereotypowym niekorzystnym obrazem danego narodu, który jest ściśle związany z trudną przeszłością. 
Stereotypy przekazują tradycję społeczną z pokolenia na pokolenie, często pomijając fakt, że dany obraz grupy przez wiele lat ewoluował. Jest prawie niemożliwe, aby taki stereotyp uległ zmianie w świadomości ludzkiej w krótszym czasie. Często nieaktualne już dowcipy są przekazywane dalej, utrwalając w ten sposób uprzedzenia i podtrzymując stereotyp.

Byłoby interesującym przedsięwzięciem rozwinięcie badań $\mathrm{w}$ aspekcie porównawczym, co mogłoby zaowocować nie tylko poszerzeniem wiedzy, ale ukazać ich cechy wspólne, a także odrębne w szerszym wymiarze kulturowym.

\section{Bibliografia}

(www 1) http://swietoszek.klp.pl/a-6198.html [dostęp: 25.09.2014].

Bańko M. (red.), 2007, Stownik języka polskiego, Warszawa.

Brzozowska D., 2008, Polski dowcip etniczny. Stereotyp a tożsamość, Opole.

Buttler D., 2001, Polski dowcip językowy, Warszawa.

Chlebda W., 1998, Stereotyp jako jedność języka, myślenia i dziatania, w: Język a Kultura, t. 12: Stereotyp jako przedmiot lingwistyki: teoria, metodologia, analizy empiryczne, red. J. Anusiewicz, J. Bartmiński, Wrocław, s. 31-41.

Dzemidok B., 1967, O komizmie, Warszawa.

Kopaliński W., 2000, Stownik wyrazów obcych i zwrotów obcojęzycznych z almanachem, Warszawa.

Libura A., Libura M., 1998, Stereotypy a sady naukowe na przykładzie niektórych podstawowych pojęć gramatycznych, w: Język a Kultura, t. 12: Stereotyp jako przedmiot lingwistyki: teoria, metodologia, analizy empiryczne, red. J. Anusiewicz, J. Bartmiński, Wrocław, s. 296-303.

Panasiuk J., 1998, O zmienności stereotypów, w: Język a Kultura, t. 12: Stereotyp jako przedmiot lingwistyki: teoria, metodologia, analizy empiryczne, red. J. Anusiewicz, J. Bartmiński, Wrocław, s. 85-97.

Quasthoff U.M., 1998, Etnocentryczne przetwarzanie informacji. Ambiwalencja funkcji stereotypów w komunikacji międzykulturowej, w: Język a Kultura, t. 12: Stereotyp jako przedmiot lingwistyki: teoria, metodologia, analizy empiryczne, red. J. Anusiewicz, J. Bartmiński, Wrocław, s. 11-30.

Walczyńska M., 1998, Jan Stanistaw Bystroń jako prekursor teorii stereotypu na gruncie polskim, w: Język a Kultura, t. 12: Stereotyp jako przedmiot lingwistyki: teoria, metodologia, analizy empiryczne, red. J. Anusiewicz, J. Bartmiński, Wrocław, s. 304-307.

\section{ŹRÓDEA INTERNETOWE CYTOWANYCH DOWCIPÓW}

http://forum.kajgana.com/threads/ [dostęp: 20-25.09.2014].

http://www.kalugerica.com/strani\%20sporedni/vicovi.htm [dostęp: 20-25.09.2014]. http://www.crnobelo.com/zabava/humor/1444-tipicen-makedonski-vic [dostęp: 23.09.2014]. http://www.vicoteka.mk/ [dostęp: 20-25.09.2014]. 